\title{
Hubungan tingkat self-compassion dengan optimisme guru dan peserta didik di masa pandemi Covid-19
}

\author{
Palasara Brahmani Laras $\left.{ }^{1 *}\right)$ \& Eka Aryani ${ }^{2}$ \\ Universitas Mercu Buana Yogyakarta ${ }^{12}$ \\ $\left.{ }^{*}\right)$ Alamat korespondensi: JI Jembatan Merah, DI Yogyakarta, 55753, Indonesia; E-mail: \\ palasara@mercubuana-yogya.ac.id
}

Article History: Received: 30/11/2020; Revised: 29/06/2021; Accepted: 30/06/2021; Published: 30/06/2021.

How to cite: Laras, P.B. \& Aryani, E. (2021). Hubungan tingkat self compassion dengan optimisme guru dan peserta didik pada masa pandemi Covid-19.

Teraputik: Jurnal Bimbingan dan Konseling, 5(1), pp. 132-140. DOI: $10.26539 /$ teraputik.51499

\begin{abstract}
Abstrak: Tujuan penelitian untuk mengetahui hubungan self-compassion dengan optimisme pada guru dan peserta didik pada masa Pandemi Covid-19. Penelitian menggunakan metode korelasi. Populasi penelitian adalah seluruh guru dan peserta didik di SMP N 1 Piyungan. Sampel penelitian 60 guru dan 60 Peserta didik. Hasil penelitian analisis korelasi terhadap tingkatan dalam Self-Compassion "sedang" memiliki hubungan yang negatif dan tidak singnifikan dengan optimis, nilai signifikansi $0,0699>0,05$ dengan nilai $r$ sebesar $-0,077$ dan SelfCompassion "rendah" memiliki hubungan yang positif dan tidak signifikan dengan optimis, nilai signifikansi 0,520>0,05 dengan nilai $r$ sebesar 0,268, sedangkan Self-Compassion "tinggi" memiliki korelasi yang positif dan signifikan terhadap optimis dengan nilai signifikansi $<0,001$ dengan nilai $r$ sebesar 0.985 yang berarti tedapat korelasi yang kuat antara Self-Compassion tinggi dan optimis. Berdasarkan hasil analisis lanjutan terhadap self-compassion dan optimisme diketahui bahwa faktor terbesar yang mengkonstruk self-compassion adalah Isolation dan faktor yang paling kecil sumbangsihnya terhadap Self-Compassion adalah Self-Jugdment, sedangkan untuk faktor yang paling besar sumbangsihnya terhadap optimis adalah "Optimis Personalisasi" dan Faktor yang paling kecil adalah "Optimis Pervasiveness".

Kata Kunci: Self-Compassion, Optimisme, Guru, Peserta Didik
\end{abstract}

Abstract: The purpose of the study was to determine the relationship between self-compassion and optimism in teachers and students during the Covid-19 pandemic. The research uses the correlation method. The research population is all teachers and students at SMP N 1 Piyungan. The research sample is 60 teachers and 60 students. The results of the correlation analysis research on the level of Self-Compassion "medium" have a negative and not significant relationship with optimism, the significance value is $0.0699>0.05$ with an $r$ value of -0.077 and Self-Compassion "low" has a positive relationship and not significant with optimism, a significance value of $0.520>0.05$ with an $r$ value of 0.268 , while Self-Compassion "high" has a positive and significant correlation with optimism with a significance value $<0.001$ with an $r$ value of 0.985 which means there is a strong correlation between High self-compassion and optimistic. Based on further analysis of self-compassion and optimism, it is known that the biggest factor that constructs self-compassion is Isolation and the factor that has the least contribution to Self-Compassion is Self-Jugdment, while the biggest factor contributing to optimism is "Personalization Optimism" and The smallest factor is "Optimistic Pervasiveness". Keywords: Self-Compassion, Optimism, Teachers, Students

\section{Pendahuluan}

Menilik fenomena yang terjadi saat ini, dunia dikejutkan dengan adanya wabah virus bernama corona Virus Diseases-19 (Covid-19). Virus covid-19, telah tersebar di penjuru dunia, dengan ratusan ribu manusia di dunia terpapar virus ini, bahkan dari korban, manusia diberitakan menjadi korban meninggal. Penularan virus ini sangat cepat dan sulit untuk menditeksi orang yang terpapar dikarenakan masa inkubasi virus covid-19 kurang lebih sekitar empat belas hari atau dua minggu sehingga banyak korban yang berjatuhan. Penularan melalui kontak antar manusia dengan kegiatan sosialnya yang tidak dapat dihindari menjadi penyebab terbesar dalam penyebaran virus covid-19. 
Belum adanya obat penawar menyebabkan orang yang terpapar menjadi semakin banyak hingga berujung pada kematian. Sulitnya penanganan wabah virus covid-19 ini, di beberapa negara terutama di Indonesia, menerapkan kebijakan sosial distancing, psyical distancing dan isolasi mandiri sebagai antisipasi penyebaran wabah ini dan memutus penyebaran covid-19. Solusi ini menjadi pilihan berat bagi setiap negara dalam menerapkan kebijakan pencegahan covid-19, karena kebijakan ini berdampak sangat signifikan terhadap segala aspek kehidupan. Masyarakat dituntut tidak hanya dengan menjaga jarak melainkan dengan bekerja atau belajar di rumah istilah lain WFH (Work From Home).

Bekerja di rumah (WFH) merupakan salah satu bentuk imbauan pemerintah dalam rangka menghentikan penyebaran pandemi Covid-19. WFH diberlakukan hampir pada semua lembaga termasuk dalam lembaga pendidikan. Adanya WFH membuat semua proses dalam kegiatan belajar mengajar (KBM) yang semula dilakukan secara langsung di ruang kelas, menjadi terhenti sementara waktu dan digantikan dengan KBM menggunakan sistem online atau daring. Para guru dan peserta didik tetap melaksanakan KBM seperti biasa, hanya saja untuk saat ini dilakukan di ruang terpisah di tempat masing-masing. Dengan cukup mempunyai fasilitas HP, jaringan yang mendukung serta kuota, kegiatan ini dapat dilakukan. Namun faktanya, setelah beberapa minggu berjalan, KBM dengan sistem online mulai menimbulkan masalah dan hambatan. Di antaranya, tidak semua anak memiliki fasilitas handphone (HP) yang memadai atau mendukung untuk belajar online. Keterbatasan sarana dan prasarana, keterbatasan biaya kuota dan jaringan internet menjadi kendala yang dirasakan tidak hanya peserta didik akan tetapi juga guru.

Berdasarkan hasil survei dari Forum Anak Nasional (Mashabi, 2020) menenukan bahwa sebanyak 58 persen anak mempunyai perasaan tidak menyenangkan selama menjalani belajar dari rumah. Tidak adanya interaksi dengan guru, teman dan lingkungan sekolah menambah kejenuhan dalam pembelajaran sistem online atau daring. Purwanto (2020) dalam penelitiannya menemukan beberapa dampak yang dirasakan oleh peserta didik selama mengikuti proses belajar di rumah, peserta didik merasa dipakasa belajar jarak jauh tanpa sarana dan prasarana yang memadai di rumah. Di lain sisi, budaya belajar secara jarak jauh merupakan hal baru, karena selama ini sistem belajar dilaksanakan melalui tatap muka, peserta didik terbiasa berinteraksi secara langsung di sekolah dengan guru dan teman-temannya, peserta didik perlu waktu beradaptasi dan menghadapi perubahan baru yang secara tidak langsung mempengaruhi daya serap belajar para peserta didik. Senada dengan peserta didik, guru sebagai pengajarpun memiliki kesulitan-kesulitan yang menjadi penghambat dalam proses kegiatan belajar jarak jauh. Tidak semua guru mempunyai kecakapan dalam menggunakan teknologi baru, internet atau media sosial sebagai sarana pendukung dalam pembelajaran.

Adanya pandemi Covid-19 memaksa para guru dan peserta didik harus dapat beradaptasi menggunakan teknologi. Situasi tersebut, memerlukan kemampuan yang ekstra dari setiap guru dan peserta didik dalam menjalankan tugas sebagai seorang pendidik dan peserta didik dengan lebih optimal. Fadillah \& Eryani (2019) mengungkapkan bahwa keyakinan diri dalam menjalankan tugas berperan penting. Menurut Primardi \& Hadjam (2011) keyakinan diri ini akan membentuk pandangan positif terhadap masa depan yang akan berakhir baik terlepas dari segala masalah yang sedang dihadapi dan kemungkinan masalah yang akan terjadi disebut optimisme lalu akan terbentuk dan terwujud pada perilaku.

Sikap optimisme, akan membentuk keyakinan pada diri sendiri bahawa ia mampu untuk membangun performa akademik yang baik dengan menciptakan suatu suasana baru dalam belajar dan percaya pada kemampuannya sendiri untuk terus maju terlepas dari masalah yang akan dihadapi (Hoy et al., 2008). Guru yang memiliki rasa keyakinan pada dirinya sendiri dalam melakukan proses belajar-mengajar, secara otomatis akan membentuk ekspektasi yang lebih tinggi pada perkembangan akademik peserta didiknya, mengeluarkan usaha yang lebih tinggi dalam mengajar dan memiliki daya tahan yang lebih tinggi saat menghadapi situasi sulit (Tschannen-Moran et al., 1998). Begitu juga peserta didik yang memiliki rasa keyakinan pada dirinya akan memiliki daya tahan yang kuat dalam menghadapi situasi sulit. Semakin tinggi rasa optimisme maka semakin tinggi motivasi belajar siswa (Noordjanah, 2013). Senada dengan itu, menurut AK \& Pradna (2012) penerapan optimisme juga akan membantu guru dan peserta didik untuk terus berdedikasi menjadi pribadi yang lebih baik. 
Individu yang cenderung optimis memiliki sumber daya pribadi yang memadai bagi pembelajaran. Hasil penelitian El-Anzi (2005) mengungkapkan bahwa optimisme dan self-esteem memiliki korelasi positif dengan prestasi akademik. Sementara itu menurut Nes \& Segerstrom (2006) menyimpulkan bahwa optimisme berasosiasi positif dengan pendekatan strategi coping yang bertujuan untuk mengeliminasi, mengurangi atau mengatur stressor dan emosi. Optimisme dapat melindungi individu melawan depresi, dapat meningkatkan prestasi dan meningkatkan kesejahteraan fisik dan mental (Seligman, 2005).

Sikap optimisme atau keyakinan diri Menurut Bandura (1997) individu yang memiliki tingkat keyakinan diri yang tinggi secara otomatis akan membentuk sense of personal efficacy. Hal ini ditandai dengan kepercayaan individu terhadap kualitas serta kemampuan diri sendiri sehingga, dapat mengatur perilaku yang akan dilakukan untuk mencapai suatu target. Kualitas dan kemampuan dari dalam diri akan dapat diterima seutuhnya setelah individu menerima segala kelemahan dan kekuatan yang ada dalam diri sendiri secara seutuhnya (K. D. Neff et al., 2007). K. Neff (2003) menambahkan bahwa sikap ini tergolong sebagai self-compassion yang berarti mengasihi diri sendiri ketika menghadapi penderitaan dengan memberikan pemahaman dan kebaikan pada diri sendiri, tanpa menghakimi kekurangan diri, melihat suatu kejadian sebagai pengalaman yang dialami semua manusia serta tidak menghindar dari penderitaan tersebut.

Menurut K. D. Neff \& McGehee (2010) menemukan bahwa ketika individu lebih memberikan pengertian kepada diri sendiri, individu tersebut akan lebih mampu mengelola emosinya pada masa- masa sulit. self-compassion merupakan salah satu bahasan yang bisa menjelaskan cara individu dapat bertahan, memahami dan menyadari makna dari sebuah kesulitan sebagai hal yang positif (Hidayati, 2016). Berdasarkan pembahasan di atas terkait dengan hubungan antara self-compassion dengan optimisme perlu dikaji untuk mengetahui keterkaitannya. Oleh karena itu penelitian ini bertujuan untuk mengetahui bagaimana hubungan self-compassion dengan optimisme pada guru dan peserta didik pada masa Pandemi Covid-19.

\section{Metode}

Pendekatan penelitian ini adalah pendekatan kuantitatif karena data penelitiannya berbentuk angka, atau data kualitatif yang dikuantifikasi (Rangkuti, 2015). Penelitian kuantitatif bertolak dari studi pendahuluan dari obyek yang diteliti (preliminary study) melalui fakta-fakta empiris untuk mendapatkan sesuatu yang benar-benar dapat digolongkan sebagai suatu masalah. Menurut Sugiono (2009) proses penelitian kuantitatif bersifat linier, yang berarti langkah-langkahnya jelas mulai dari proses perumusan masalah, penentuan teori, pengembangan hipotesis, pengumpulan data, analisis data hingga pembuatan kesimpulan serta saran.

Metode penelitian yang peneliti gunakan adalah penelitian korelasional. Menurut Gay (Sukardi, 2008) penelitian korelasi merupakan salah satu bagian dari penelitian ex-post facto karena biasanya peneliti tidak memanipulasi keadaan variabel yang ada dan langsung mencari keberadaan hubungan serta tingkat hubungan antar variabelnya. Penelitian dilaksanakan pada bulan Mei sampai dengan bulan Juli 2020. Di sekolah SMPN 1 Piyungan dengan alamat JI. Wonosari km No.14, Sandeyan, Srimulyo, Kec. Piyungan, Bantul, Daerah Istimewa Yogyakarta 55792, Indonesia.

Populasi penelitian ini adalah seluruh guru dan peserta didik di SMP N 1 Piyungan. Sampel penelitian mengacu pada pendapat dari Sugiyono (2011) untuk penentuan sampel dengan jumlah populasi 120 dan taraf signifikansi 5\% adalah 89 orang. Namun dikarenakan wabah Covid-19 ini, serta mengenai kriteria sampel yang penulis tetapkan, sampel yang bisa didapat hanya sebanyak 60 Guru dan 60 Peserta didik. Maka dari itu hal ini akan penulis masukan ke keterbatasan penelitian. Teknik pengambilan sampel yang digunakan adalah non-probability sampling, yaitu teknik yang tidak memberikan peluang atau kesempatan sama bagi setiap unsur atau anggota populasi untuk dipilih menjadi sampel. Secara lebih rinci menggunakan jenis purposive sampling, yaitu teknik penentuan sampel dengan pertimbangan atau kriteria tertentu (Sugiyono, 2008). 
Instrumen yang digunakan berupa kuesioner (angket) berbentuk pernyataan yang disesuaikan dengan aspek self-compassion dan aspek optimisme. Penelitian ini menggunakan kuisioner instrument self-compassion dan instrument optimisme. Pada skoring setiap alternatif jawaban yang diberikan peserta didik diberi skor 5 jika memilih jawaban Sangat Sesuai, skor 4 jika memilih pernyataan Sesuai, skor 3 jika pernyataan Cukup Sesuai, skor 2 jika pernyataan Tidak Sesuai, skor 1 jika pernyataan Sangat Tidak Sesuai. Untuk menghitung total nilai selfcompassion, perolehan skor pada item-item negatif yakni self-judgment, isolation dan overidentification memperoleh nilai yang berbalik dengan item-item positif $(1=5,2=4,3=3,4=2,5=1)$ kemudian hitung total rata-rata. Dan untuk instrument optimisme terbagi dalam 3 aspek yakni Optimis Permanensi, Optimis Pervasiveness, Optimis Personalisasi memiliki nilai positif dan negative yang tertuang dalam skala penyekorannya. Pada penelitian ini, analisis data yang digunakan adalah dengan menghitung skor maksimal dan minimal dari nilai skala kemampuan pemecahan masalah serta menghitung skor masing-masing subyek. Penentuan kategori kecenderungan dari tiap-tiap variabel didasarkan pada norma atau ketentuan kategori. Kategori tersebut menurut Burhan Nurgiyantoro (2003:109) sebagai berikut:



Keterangan :

$$
\begin{array}{ll}
\mu & =\text { Mean ideal } \\
\sigma & =\text { Standar Deviasi } \\
X & =\text { Skor yang diperoleh }
\end{array}
$$

\section{Hasil dan Diskusi}

Tahapan awal sebelum melakukan analisis lebih lanjut dan untuk menjawab pertanyaan pada penelitian ini, perlu di ketahui apakah sampel yang digunakan telah memenuhi aspek ketercupakan sampel. Uji kelayakan sampel menggunakan KMO and Bartlett's Test. Berikut Tabel Output SPSS Versi 23.

Tabel 1. Hasil Uji KMO

\begin{tabular}{lll}
\hline Kaiser-Meyer-Olkin Measure of Sampling Adequacy. & 0,624 \\
\cline { 2 - 3 } Bartlett's Test of Sphericity & Approx. Chi-Square & 157,653 \\
\cline { 2 - 3 } & Sf & 91 \\
\hline
\end{tabular}

Berdasarkan tabel di atas di atas menunjukkan nilai KMO yaitu sebesar 0,62>0,50. Yang berarti bahwa sampel telah memenuhi aspek ketercukupan Sehingga dapat simpulkan bahwa sampel dapat diuji lanjut.

\section{Uji Keterbacaan Instrumen}

Setelah sampel memenuhi aspek ketercukupan, tahapan selanjutnya adalah menguji keterbacaan instrumen untuk menganalisis instrument (angket) apakah sudah memiliki tingkat kesulitan yang beragam, untuk uji ini menggunakan aplikasi Winstep.

Analisis menggunakan model Rasch menghasilkan analisis statistik kesesuaian (fit statistics) yang memberikan informasi pada peneliti apakah data yang didapatkan secara ideal menggambarkan bahwa orang yang mempunyai abilitas tinggi memberikan pola jawaban terhadap item sesuai dengan tingkat kesulitannya. Parameter yang digunakan adalah infit dan outfit dari kuadrat tengah (mean square) dan nilai terstandarkan (standardized values). 
Berikut output Winstep pada Gambar di bawah ini.

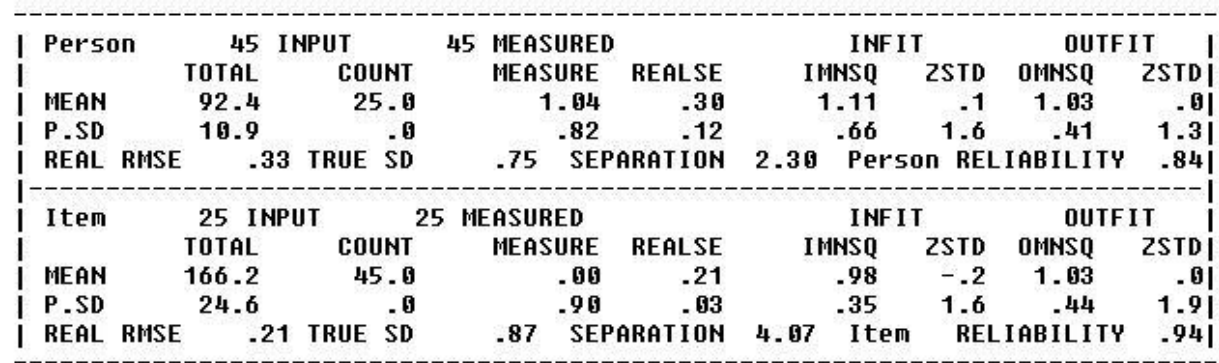

Gambar 1. Output Winstep 1

Berdasarkan hasil analisis data di atas angket memiliki nilai Separation 4,07 dan item Reliability 0,94. Hal ini berarti angket berfungsi cukup baik karena memiliki rata-rata tingkat kesulitan yang beragam. Sedangkan untuk subjek hanya memiliki Separation 2,30 dan person Reliability 0,84 . Ini berarti subjek sangat variatif karena memiliki range ability yang luas.

Selanjutnya untuk mengecek penyebaran setiap penyataan pada angket dan Responden dapat dilihat pada Gambar 2 di bawah ini.

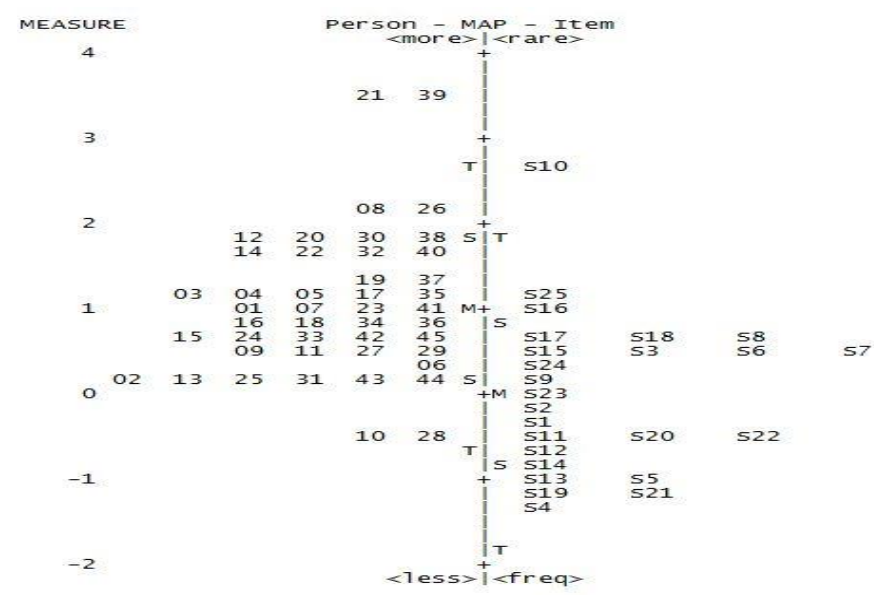

Gambar 2. Ouput Winstep 2

Terlihat bahwa identifikai peserta test atau person ada di bagian kiri, yang menunjukkan abilitas dari setiap peserta tes dalam skala logit; sedangkan pada sebelah kanan adalah kontinum tingkat kesulitan item. Untuk membuat peta lebih informatif maka modifikasi berdasar jenis kelamin (sebelah kiri), dan jenis pertanyaan dari soal yang diberikan (kanan) untuk mengetahui secara lebih tepat informasi tentang peserta test dan butir soal yang diberikan. Berdasarkan gambar 2 di atas menunjukan bahwa kemampuan rata-rata respon lebih tinggi dari perntanyaan pada angket yang diberikan, sehingga dapat disimpulkan bahwa para responden dapat menjawab angket dengan baik.

\section{Uji Korealsi Self Compassion dan Optimisme}

Tahapan analisis berikutnya yaitu uji korelasi setelah sampel dinyatakan memenuhi syarat dan instrumen yang digunakan layak, sehingga analisis uji korelasi dapat memberikan makna, dari hasil uji korelasi dengan menggunakan JASP 11.1. Pada tahapan ini uji korelasi terhadap self-compassion dan Optimisme, berikut output JASP sebagaimana tabel 2 di bawah ini. 
Tabel 2. Uji Pearson Correlations

\begin{tabular}{llll}
\hline & Pearson's $r$ & $p$ & \\
\hline SELF - OPT & 0.418 & $* *$ & 0.004 \\
\hline
\end{tabular}

${ }^{*} p<.05,{ }^{* *} p<.01,{ }^{* * *} p<.001$

Berdasarkan tabel di atas menunujukkan bahwa korelasi self-compassion dan Optimisme adalah positif dan singnifikan terlihat dari nilai sig 0,004<0,01 dengan nilai $r$ sebesar 0,418 . Yang berarti bahwa korelasi positif menunjukkan kedua variabel memiliki hubungan yang searah dengan nilai korelasi antar variable cukup kuat.

Uji Korelasi Optimisme dengan memperhatikan tingkatan dalam Self Compassion

Selanjutnya uji korelasi pada tahapan ini adalah menguji hubungan antara tingkatan selfcompassion yang terdiri dari tinggi, sedang, dan rendah dengan optimisme. Sehingga dapat diketahui tingkatan mana dari self-compassion berkorelasi dengan optimisme. Berikut hasil uji korelasi dengan menggunakan JASP 11.1 sebagaimana tabel 3 di bawah ini.

Tabel 3. Pearson Correlations Berdasarkan Tingkatan

\begin{tabular}{lll}
\hline \multicolumn{1}{c}{ Pearson's $r p$} & \\
\hline OPTIMIS - SEDANG & -0.077 & 0.699 \\
\hline OPTIMIS - TINGGI & $0.985^{* * *}<.001$ \\
\hline OPTIMIS - RENDAH & 0.268 & 0.520 \\
\hline
\end{tabular}

${ }^{*} p<.05,{ }^{* *} p<.01,{ }^{* * *} p<.001$

Tabel di atas menunjukan bahwa (1) self-compassion Sedang memiliki hubungan yang negatif dan tidak singnifikan dengan optimis, nilai signifikansi 0,0699>0,05 dengan nilai $r$ sebesar $-0,077$, (2) self-compassion Rendah memiliki hubungan yang positif dan tidak signifikan dengan optimis, nilai signifikansi 0,520>0,05 dengan nilai r sebesar 0,268, dan (3) Self Compassion tinggi memiliki hubungan positif dan singfikan dengan optimis, nilai signifikansi $<0,001$ dengan nilai $r$ sebesar 0.985 yang berarti tedapat hubungan yang kuat antara self-compassion tinggi dan optimis. Berdasarkan hasil analisis korelasi terhadap tingkatan dalam self-compassion maka dapat disimpulkan bahwa self-compassion sedang dan self-compassion rendah tidak terdapat hubungan yang signifikan dengan optimis, sedangkan self-compassion tinggi memiliki hubungan yang positif dan signifikan terhadap optimis dan memilki hubungan yang sangat kuat.

\section{Uji Lanjut}

Untuk mengkofirmasi konstruk koseptual dimensi, sub dimensi dan indikator selfcompassion dan optimis. Untuk mengetahui dimensi yang memiliki sumbangsih terbesar terhadap variabel self-compassion dan optimis menggunakan Lisrel 8,5. Sebelum menganalisis nilai faktor loading maka Berdasarkan hasil analisis data dengan Second order analisis faktor konfirmasi diperoleh model fit. Proses analisa dilakukan dua kali, yaitu analisis awal dan Reanalysis. Proses reanalisis dilakukan untuk meningkatkan model fit pada model penelitian dengan modifikasi internal specification errors yaitu menghilangkan (atau dimasukkannya) parameter-parameter yang penting (tidak relevan) pada variabel-variabel dalam satu model (Ghozal\& Fuad, 2008). Hasil Analisis disajikan pada Tabel 4.

Tabel 4. Data Output CFA Second Order Berdasarkan Absolute Fit Indices

\begin{tabular}{llllllll}
\hline & \multirow{2}{*}{$\begin{array}{l}\text { Goodness of } \\
\text { Fit }\end{array}$} & \multicolumn{3}{l}{ Analisis Awal } & \multicolumn{3}{l}{ Reanalisis } \\
\cline { 3 - 8 } & & Cut of Value & Value & Decision & Cut of Value & Value & Decision \\
\hline 1 & Chi-Square & $\leq 2 x d f$ & 42.79 & Not Good & $\leq 2 x d f$ & 22.45 & Good \\
\hline
\end{tabular}




\begin{tabular}{llcllcll}
\hline & \multicolumn{9}{c}{$\leq 2 \times 26$} & & & $\leq 2 \times 24$ & & \\
\hline 2 & GFI & $\geq 90$ & 0.82 & Not Good & $\geq 90$ & 0.90 & Good \\
\hline 3 & RMSEA & $<0.05$ & 0.121 & Good & $<0.05$ & 0.00 & Good \\
\hline 4 & P Value & $\geq 0.05$ & 0.20 & Not Good & $\geq 0.05$ & 0.54 & Good \\
\hline
\end{tabular}

Berdasarkan tabel di atas menunjukkan bahwa model kurang fit pada analisis awal sesuai dengan nilai absulte fit indices, baik nilai Chi-Square, GFI, dan P Value masih belum memenuhi standar, sedangkan nilai RMSEA telah memenuhi yaitu sebesar $0.121>0.05$, sehingga dapat disimpulkan bahwa analisis CFA perlu dilakukan perbaikan dengan melakukan Reanalysis. Setelah dilakukan Reanalysis, baik nilai Chi-Square, GFI, RMSEA, dan P Value telah memenuhi standar nilai sehingga dapat dinyatakan bahwa model fit. Model tersebut juga dapat dilihat pada gambar 3 di bawah ini.

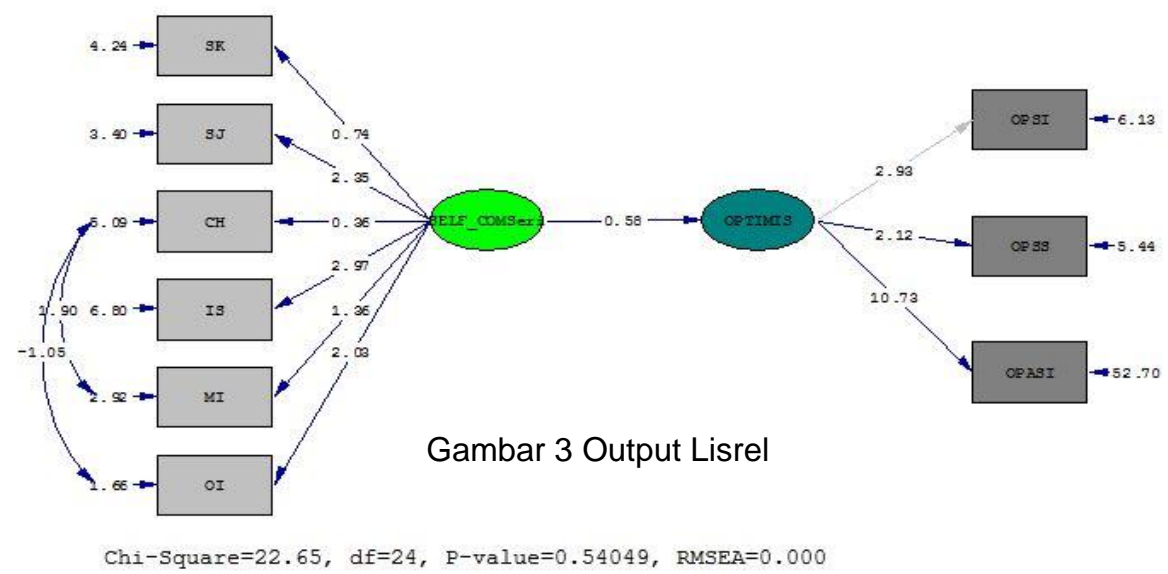

Pada gambar di atas dapat menunjukkan bahwa nilai loading factor $>0.30$ sehungga dapat disimpulkan bahwa semua indicator valid, sehingga dapat di interpetasikan lebih lanjut, yaitu (1) self-compassion memiliki pengaruh terhadap optimis, (2) Faktor Terbesar yang mengkonstruk self-compassion adalah Isolation dan Faktor yang paling kecil sumbangsihnya terhadap selfcompassion adalah self-jugdment, (3) Faktor yang paling besar sumbangsihnya terhdap optimis adalah OPASI (Optimis Personalisasi) dan Faktor yang paling kecil adalah OPSS (Optimis Pervasiveness.

Berdasarkan hasil penelitian mengenai hubungan tingkat self-compassion dengan optimisme pada guru dan peserta didik selama masa pandemic Covid-19 dapat disarankan sebagai berikut:

1. Dengan diketahuinya hubungan tingkat self-compassion dengan optimisme pada guru dan peserta didik selama masa pandemic Covid-19 diharapkan ada tindakan atau penelitian lanjutan mengenai treatment berupa kegiatan atau layanan untuk mengembangkan selfcompassion dan optimisme padaguru dan peserta didik di lingkungan sekolah.

2. Untuk instrument yang mengungkap self-compassion dan optimisme masih banyak kekurangan dan belum komprehensif sehingga perlu dikaji dengan lebih mendalam mengenai faktor-faktor yang mempengaruhi self-compassion dan optimisme.

3. Sebaran instrument yang dilakukan hanya terbatas melewati via website google form, sehingga yang mengisi hanya responden yang memiliki akun gmail. Untuk lebih komprehensif bisa terwakili dapat juga menggunakan sebaran angket yang di sebarkan secara langsung.

\section{Simpulan}

Berdasarkan hasil dari penelitian mengenai hubungan tingkat self-compassion dengan optimisme pada guru dan peserta didik selama masa pandemic Covid-19 dapat diambil kesimpulannya. Secara umum dapat di gambarkan bahwa Berdasarkan hasil analisis korelasi 
terhadap tingkatan dalam self-compassion maka dapat disimpulkan bahwa self-compassion "sedang" memiliki hubungan yang negatif dan tidak singnifikan dengan optimis, nilai signifikansi 0,0699>0,05 dengan nilai $r$ sebesar -0,077dan self-compassion rendah memiliki hubungan yang positif dan tidak signifikan dengan optimis, nilai signifikansi 0,520>0,05 dengan nilai $r$ sebesar 0,268 , sedangkan self-compassion tinggi memiliki hubungan yang positif dan signifikan terhadap optimis dengan nilai signifikansi $<0,001$ dengan nilai $r$ sebesar 0.985 yang berarti tedapat hubungan yang kuat antara self-compassion tinggi dan optimis.

Berdasarkan hasil analisis lanjutan terhadap self-compassion dan optimisme dapat diketahui bahwa faktor terbesar yang mengkonstruk self-compassion adalah Isolation dan Faktor yang paling kecil sumbangsihnya terhadap self-compassion adalah self-jugdment, sedangkan untuk faktor yang paling besar sumbangsihnya terhdap optimis adalah OPASI (Optimis Personalisasi) dan Faktor yang paling kecil adalah OPSS (Optimis Pervasiveness).

\section{Ucapan Terima Kasih}

Dalam proses penelitian hingga terbit jurnal ini, tidak lepas dari bantuan dan kerjasama dari berbagai pihak. Oleh karena itu, peneliti mengucapkan terima kasih kepada:

1. Rektor Universitas Mercu Buana Yogyakarta

2. Dekan Fakultas Keguruan dan IImu Pendidikan Universitas Mercu Buana Yogyakarta

3. Pimpinan Lembaga Pengabdian Kepada Mayarakat Universitas Mercu Buana Yogyakarta

4. Ketua Program Studi Bimbingan dan Konseling Universitas Mercu Buana Yogyakarta

5. Kepala Sekolah SMPN 1 Piyungan sebagai Mitra dalam Pelaksanaan Pengabdian

6. Guru BK dan Peserta didik SMPN 1 Piyungan dan berbagai pihak yang tidak dapat kami sebutkan satu persatu yang telah membantu terlaksananya kegiatan ini.

\section{Daftar Rujukan}

AK, R. D., \& Pradna, P. (2012). Resiliensi guru di sekolah terpencil. Jurnal Psikologi Pendidikan Dan Perkembangan, 1(02).

Bandura, A. (1997). The anatomy of stages of change. American Journal of Health Promotion: AJHP, 12(1), 8-10.

El-Anzi, F. O. (2005). Academic achievement and its relationship with anxiety, self-esteem, optimism, and pessimism in Kuwaiti students. Social Behavior and Personality: An International Journal, 33(1), 95-104.

Fadillah, A., \& Eryani, R. D. (2019). Hubungan Dukungan Sosial dengan Self Efficacy Pada Guru Sekolah Luar Biasa Bina Anugrah di Lembang Bandung.

Hidayati, D. S. (2016). Self compassion dan loneliness. Jurnal IImiah Psikologi Terapan, 3(1), 154-164.

Hoy, A. W., Hoy, W. K., \& Kurz, N. M. (2008). Teacher's academic optimism: The development and test of a new construct. Teaching and Teacher Education, 24(4), 821-835.

Mashabi, S. (2020). Survei Kemen PPPA: 58 Persen Responden Tak Senang Belajar dari Rumah. Kompas.Com. https://nasional.kompas.com/read/2020/04/11/13511231/surveikemen-pppa-58-persen-responden-tak-senang-belajar-dari-rumah

Neff, K. (2003). Self-compassion: An alternative conceptualization of a healthy attitude toward oneself. Self and Identity, 2(2), 85-101.

Neff, K. D., Kirkpatrick, K. L., \& Rude, S. S. (2007). Self-compassion and adaptive psychological functioning. Journal of Research in Personality, 41(1), 139-154.

Neff, K. D., \& McGehee, P. (2010). Self-compassion and psychological resilience among adolescents and young adults. Self and ldentity, 9(3), 225-240.

Nes, L. S., \& Segerstrom, S. C. (2006). Dispositional optimism and coping: A meta-analytic review. Personality and Social Psychology Review, 10(3), 235-251.

Noordjanah, A. (2013). hubungan harga diri dan optimisme dengan motivasi belajar pada siswa man maguwoharjo sleman Yogyakarta. Jurnal Psikologi Terapan Dan Pendidikan, 1(1). 
Primardi, A., \& Hadjam, M. N. R. (2011). Optimisme, harapan, dukungan sosial keluarga, dan kualitas hidup orang dengan epilepsi. Jurnal Psikologi, 3(2).

Purwanto, A., Pramono, R., Asbari, M., Hyun, C. C., Wijayanti, L. M., \& Putri, R. S. (2020). Studi eksploratif dampak pandemi COVID-19 terhadap proses pembelajaran online di sekolah dasar. EduPsyCouns: Journal of Education, Psychology and Counseling, 2(1), 1-12.

Rangkuti, F. (2015). Personal SWOT analysis. Gramedia Pustaka Utama.

Seligman, M. E. P. (2005). Authentic happiness menciptakan kebahagiaan dengan psikologi positif/oleh Martin EP Seligman; Penerjemah: Eva Yulia Nukman.

Sugiono. (2009). Metode Penelitian Pendidikan Pendekatan Kuantitatif, Kualitatif, dan R\&D. Alfabeta.

Sugiyo. (2011). Manajemen Bimbingan dan Konseling di Sekolah. Widya Karya.

Sugiyono. (2008). Metode penelitian pendidikan:(pendekatan kuantitatif, kualitatif dan $R$ \& D). Alfabeta.

Sukardi, H. M. (2008). Evaluasi pendidikan prinsip dan operasionalnya. Jakarta: Bumi Aksara.

Tschannen-Moran, M., Hoy, A. W., \& Hoy, W. K. (1998). Teacher efficacy: Its meaning and measure. Review of Educational Research, 68(2), 202-248.

\section{Competing interests:}

The authors declare that they have no significant competing financial, professional or personal interests that might have influenced the performance or presentation of the work described in this manuscript. 